\title{
Front Matter: Volume 6682
}

, "Front Matter: Volume 6682," Proc. SPIE 6682, Polarization Science and Remote Sensing III, 668201 (26 October 2007); doi: 10.1117/12.759499

SPIE Event: Optical Engineering + Applications, 2007, San Diego, California, United SPIE. States 


\section{PROCEEDINGS OF SPIE}

\section{Polarization Science and Remote Sensing III}

Joseph A. Shaw

J. Scott Tyo

Editors

29-30 August 2007

San Diego, California, USA

Sponsored and Published by

SPIE

Volume 6682 
The papers included in this volume were part of the technical conference cited on the cover and title page. Papers were selected and subject to review by the editors and conference program committee. Some conference presentations may not be available for publication. The papers published in these proceedings reflect the work and thoughts of the authors and are published herein as submitted. The publisher is not responsible for the validity of the information or for any outcomes resulting from reliance thereon.

Please use the following format to cite material from this book:

Author(s), "Title of Paper," in Polarization Science and Remote Sensing III, edited by Joseph A. Shaw, J. Scott Tyo, Proceedings of SPIE Vol. 6682 (SPIE, Bellingham, WA, 2007) Article CID Number.

ISSN 0277-786X

ISBN 9780819468307

Published by

SPIE

P.O. Box 10, Bellingham, Washington 98227-0010 USA

Telephone +1 3606763290 (Pacific Time) · Fax +1 3606471445

SPIE.org

Copyright (C 2007, Society of Photo-Optical Instrumentation Engineers

Copying of material in this book for internal or personal use, or for the internal or personal use of specific clients, beyond the fair use provisions granted by the U.S. Copyright Law is authorized by SPIE subject to payment of copying fees. The Transactional Reporting Service base fee for this volume is $\$ 18.00$ per article (or portion thereof), which should be paid directly to the Copyright Clearance Center (CCC), 222 Rosewood Drive, Danvers, MA 01923. Payment may also be made electronically through CCC Online at copyright.com. Other copying for republication, resale, advertising or promotion, or any form of systematic or multiple reproduction of any material in this book is prohibited except with permission in writing from the publisher. The CCC fee code is $0277-786 \times / 07 / \$ 18.00$.

Printed in the United States of America.

Publication of record for individual papers is online in the SPIE Digital Library.

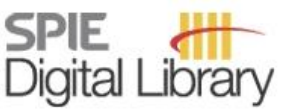

SPIEDigitallibrary.org

Paper Numbering: Proceedings of SPIE follow an e-First publication model, with papers published first online and then in print and on CD-ROM. Papers are published as they are submitted and meet publication criteria. A unique, consistent, permanent citation identifier (CID) number is assigned to each article at the time of the first publication. Utilization of CIDs allows articles to be fully citable as soon they are published online, and connects the same identifier to all online, print, and electronic versions of the publication. SPIE uses a six-digit CID article numbering system in which:

- The first four digits correspond to the SPIE volume number.

- The last two digits indicate publication order within the volume using a Base 36 numbering system employing both numerals and letters. These two-number sets start with 00, 01, 02, 03, 04, 05, $06,07,08,09,0 A, 0 B \ldots 0 Z$, followed by $10-12,20-2 Z$, etc.

The CID number appears on each page of the manuscript. The complete citation is used on the first page, and an abbreviated version on subsequent pages. Numbers in the index correspond to the last two digits of the six-digit CID number. 


\section{Contents}

$\begin{array}{ll}\text { vii } & \text { Conference Committee } \\ \text { ix Introduction }\end{array}$

SESSION 1 POLARIMETRIC AND SPECTROPOLARIMETRIC IMAGING I

668203 Channeled spectroscopic polarization state generator (CSPSG) and its application to spectroscopic measurement of Mueller matrix (Invited Paper) [6682-02]

K. Oka, S. Endo, A. Taniguchi, Hokkaido Univ. (Japan); H. Okabe, Omron Corp. (Japan)

$668204 \quad$ All-sky polarization imaging [6682-03]

N. J. Pust, J. A. Shaw, Montana State Univ. (USA)

668205 High-speed portable polarimeter using a ferroelectric liquid crystal modulator [6682-04] L. Bigué, N. Cheney, Lab. Modélisation Intelligence Processus Systèmes, Univ. de Haute Alsace, ENSISA-Lumière (France)

\section{SESSION 2 POLARIMETRIC AND SPECTROPOLARIMETRIC IMAGING II}

668206 Image segmentation from multi-look passive polarimetric imagery (Invited Paper)

[6682-05]

V. Thilak, D. G. Voelz, C. D. Creusere, New Mexico State Univ. (USA)

668207 Snapshot Mueller matrix spectropolarimetry [6682-06]

N. Hagen, E. L. Dereniak, College of Optical Sciences, Univ. of Arizona (USA)

668208 Performance predictions for micro-polarizer array imaging polarimeters [6682-07]

M. W. Jones, C. M. Persons, Digital Fusion Solutions, Inc. (USA)

668209 Mitigation of image artifacts in LWIR microgrid polarimeter images [6682-08]

B. M. Ratliff, College of Optical Sciences, Univ. of Arizona (USA) and Applied Technology Associates (USA); J. S. Tyo, College of Optical Sciences, Univ. of Arizona (USA); J. K. Boger, W. T. Black, D. M. Bowers, Applied Technology Associates (USA); R. Kumar, Univ. of New Mexico (USA)

\section{SESSION $3 \quad$ POLARIMETRIC AND SPECTROPOLARIMETRIC IMAGING III}

$66820 \mathrm{~A}$ Information enhancement, metrics, and data fusion in spectral and polarimetric images of natural scenes (Invited Paper) [6682-09]

M. J. Duggin, W. R. Glass, E. R. Cabot, Air Force Research Lab. (USA); D. Bowers, D. Wellems, Applied Technology Associates (USA); P. Alsing, Air Force Research Lab. (USA)

6682 OB Design of a dual use imager incorporating polarimetric capabilities [6682-10]

S. Moultrie, M. Roche, A. Lompado, D. Chenault, Polaris Sensor Technologies, Inc. (USA) 
$66820 \mathrm{C}$ Polarimetric scene modeling in the thermal infrared [6682-11]

M. G. Gartley, S. D. Brown, A. D. Goodenough, N. J. Sanders, J. R. Schott, Rochester Institute of Technology (USA)

\section{SESSION 4 SCATTERING: COHERENCE AND POLARIZATION}

6682 OD Non-goniometric scatterometry: a review (Invited Paper) [6682-12]

C. Hahlweg, H. Rothe, Helmut Schmidt Univ. (Germany)

6682 OE Coherent backscatter: measurement of the retroreflective BRDF peak exhibited by several surfaces relevant to ladar applications (Invited Paper) [6682-13]

T. J. Papetti, W. E. Walker, C. E. Keffer, EDO-CAS, Inc. (USA); B. E. Johnson, U.S. Army Space and Missile Defense Command (USA)

6682 OF Using polarized variable coherence tomography to estimate polarimetric BRDF from monostatic data [6682-14]

J. S. Tyo, T. S. Turner, College of Optical Sciences, Univ. of Arizona (USA)

$66820 \mathrm{G}$ Vector electromagnetic scattering from random surfaces with infinite slopes using the Kirchhoff approximation (Invited Paper) [6682-15]

N. C. Bruce, Univ. Nacional Autónoma de México (Mexico)

$6682 \mathrm{OH}$ Coherence versus radiance formulations of surface scattering (Invited Paper) [6682-16]

B. G. Hoover, Advanced Optical Technologies (USA); V. L. Gamiz, Air Force Research Lab. (USA)

\section{SESSION 5 POLARIMETRIC CALIBRATION AND MATHEMATICS}

6682 Ol Degrees of freedom in depolarizing Mueller matrices (Invited Paper) [6682-17]

R. A. Chipman, College of Optical Sciences, Univ. of Arizona (USA)

6682 0J Transmission ellipsometry on unsupported film/pellicle: closed-form inversion [6682-18] A. R. M. Zaghloul, M. Elshazly-Zaghloul, ITR Technologies, Inc. (USA); Y. A. Zaghloul, Georgia Institute of Technology (USA) and ITR Technologies, Inc. (USA)

6682 OK A proposed standard method for polarimetric calibration and calibration verification [6682-19]

C. M. Persons, M. W. Jones, C. A. Farlow, L. D. Morell, M. G. Gulley, K. D. Spradley, Digital Fusion Solutions, Inc. (USA)

$66820 \mathrm{M}$ Truncated singular value decomposition method for calibrating a Stokes polarimeter [6682-21]

B. Boulbry, National Institute of Standards and Technology (USA); J. C. Ramella-Roman, The Catholic Univ. of America (USA); T. A. Germer, National Institute of Standards and Technology (USA) 
6682 ON Characterizing dielectric tensors from angle-of-incidence Mueller matrix images [6682-22]

P. K. Smith, R. A. Chipman, College of Optical Sciences, Univ. of Arizona (USA)

668200 Estimation of incidence and reflection angles from passive polarimetric imagery: extension to out-of-plane scattering [6682-23]

A. Pamba, V. Thilak, D. G. Voelz, C. D. Creusere, New Mexico State Univ. (USA)

$66820 Q \quad$ Characterization of thermobonded nonwovens by polarimetric imaging [6682-25]

M. Tourlonias, Lab. de Physique et Mécanique Textiles, CNRS, ENSISA-Werner, Univ. de Haute-Alsace (France) and Lab. Modélisation Intelligence Processus Systèmes, ENSISALumière, Univ. de Haute-Alsace (France); L. Bigué, Lab. Modélisation Intelligence Processus Systèmes, ENSISA-Lumière, Univ. de Haute-Alsace (France); M.-A. Bueno, Lab. de Physique et Mécanique Textiles, CNRS, ENSISA-Werner, Univ. de Haute-Alsace (France)

\section{SESSION 7 ACTIVE POLARIMETRY}

6682 OS Laser polarimeter as an invariant monitor (Invited Paper) [6682-27]

J. S. Tyo, College of Optical Sciences, Univ. of Arizona (USA); B. G. Hoover, Advanced Optical Technologies (USA)

6682 OT Development of a pulse laser source-operated achromatic dual-rotating-retarder polarimeter designed for hyper-Rayleigh scattering measurements [6682-28] P. Lemaillet, S. Rivet, F. Pellen, B. Le Jeune, J. Cariou, Lab. de Spectrométrie et Optique Laser, Univ. de Bretagne Occidentale (France)

6682 OU Polarization imaging light scattering facility [6682-30]

H. Noble, G. A. Smith, W. S. Lam, S. McClain, R. A. Chipman, College of Optical Sciences, Univ. of Arizona (USA)

\section{SESSION $8 \quad$ POLARIZATION-SENSITIVE OPTICAL COMPONENTS AND SYSTEMS}

6682 OV Low polarization optical system design [6682-31]

A.-B. Mahler, P. K. Smith, R. A. Chipman, College of Optical Sciences, Univ. of Arizona (USA)

6682 OW Polarization measurements on SUMI's TVLS gratings [6682-32]

K. Kobayashi, E. A. West, J. M. Davis, G. A. Gary, NASA Marshall Space Flight Ctr. (USA)

6682 OX A polarization modulator for the far infrared (terhahertz waves) [6682-33]

T. C. Oakberg, Hinds Instruments, Inc. (USA); T. Akiyama, National Institute for Fusion Science (Japan); K. Nakayama, Chubu Univ. (Japan)

6682 OY Spatially inhomogeneous polarization in laser beam shaping [6682-34]

B. Hao, J. Leger, Univ. of Minnesota (USA)

$66820 Z$ Properties of the polarization ray tracing matrix [6682-35]

G. Yun, K. Crabtree, R. A. Chipman, College of Optical Sciences, Univ. of Arizona (USA) 
668210 Study of $\mathrm{CaF}_{2}$ samples using DUV birefringence measurement and $\mathrm{x}$-ray diffraction techniques [6682-36]

B. Wang, Hinds Instruments, Inc. (USA); W. Rosch, Corning, Inc. (USA)

668211 Achromatic polarization gratings as highly efficient thin-film polarizing beamsplitters for broadband light [6682-37]

C. Oh, M. J. Escuti, North Carolina State Univ. (USA)

\section{POSTER SESSION}

668212 Methods and means of polarization parameter control in biotissue imaging polarimetry [6682-38]

S. Y. Tuzhanskyy, Vinnytsia National Technical Univ. (Ukraine)

668213 Design of a hybrid division of aperture/division of focal plane polarimeter [6682-39]

H. Wei, J. S. Tyo, T. S. Turner, College of Optical Sciences, Univ. of Arizona (USA)

668214 Analysis of generalized polarimetric measurement equation [6682-41]

S. N. Savenkov, Kiev Taras Shevchenko Univ. (Ukraine)

668215 Initial results of a simultaneous Stokes imaging polarimeter [6682-42]

E. de Leon, R. Brandt, A. Phenis, M. Virgen, Lockheed Martin Advanced Technology Ctr. (USA)

668218 Motion-based nonuniformity correction in DoFP polarimeters [6682-45]

R. Kumar, Univ. of New Mexico (USA); J. S. Tyo, B. M. Ratliff, College of Optical Sciences, Univ. of Arizona (USA)

668219 Polarization scattering from a Spectralon calibration sample [6682-46]

H. Noble, W.-S. T. Lam, G. Smith, S. McClain, R. A. Chipman, College of Optical Sciences, Univ. of Arizona (USA)

Author Index 


\title{
Conference Committee
}

\author{
Conference Chairs
}

Joseph A. Shaw, Montana State University (USA)

J. Scott Tyo, College of Optical Sciences, University of Arizona (USA)

Program Committee

Alan J. Ames, Ball Aerospace and Technologies Corporation (USA)

David B. Chenault, Polaris Sensor Technologies, Inc. (USA)

Russell A. Chipman, College of Optical Sciences, University of Arizona (USA)

Aristide C. Dogariu, College of Optics and Photonics, University of Central Florida (USA)

Michael J. Duggin, Air Force Research Laboratory (USA)

Dennis H. Goldstein, Air Force Research Laboratory (USA)

Brian G. Hoover, Advanced Optical Technologies (USA)

Yoav Y. Schechner, Technion-Israel Institute of Technology (Israel)

Session Chairs

$1 \quad$ Polarimetric and Spectropolarimetric Imaging I

Michael J. Duggin, Air Force Research Laboratory (USA)

2 Polarimetric and Spectropolarimetric Imaging II

David B. Chenault, Polaris Sensor Technologies, Inc. (USA)

3 Polarimetric and Spectropolarimetric Imaging III

Nathan Hagen, College of Optical Sciences, University of Arizona (USA)

4 Scattering: Coherence and Polarization

Brian G. Hoover, Advanced Optical Technologies (USA)

$5 \quad$ Polarimetric Calibration and Mathematics

J. Scott Tyo, College of Optical Sciences, University of Arizona (USA)

6 Polarimetric Interaction with Media, Materials, and Surfaces

Alan J. Ames, Ball Aerospace and Technologies Corporation (USA)

7 Active Polarimetry

Joseph A. Shaw, Montana State University (USA) 
8 Polarization-Sensitive Optical Components and Systems

Russell A. Chipman, College of Optical Sciences, University of Arizona (USA) 


\section{Introduction}

The science and applications of polarization continue to expand in sophistication and scope. This proceedings volume represents theoretical and experimental research on optical polarization that was presented at the Polarization Science and Remote Sensing III conference in San Diego, California, during August 29-30, 2007. Conferences under this name were held previously in San Diego in 2005 and 2003, in alternate years with our sister conference, Polarization: Measurement, Analysis, and Remote Sensing, currently chaired by Drs. David Chenault and Dennis Goldstein.

This conference included three sessions on polarization imaging, a very successful special session on coherence and polarization in scattering organized by Dr. Brian Hoover, and the following individual sessions: Polarization Calibration and Mathematics; Polarization Interaction with Media, Materials, and Surfaces; Active Polarimetry; Polarization-sensitive Optical Components and Systems; and a poster session with multiple high-quality contributions that attracted significant interest. At this conference we benefited from notably high-quality presentations and professional interactions.

We extend our gratitude to all the participants of this conference, the session chairs, the conference organizing committee (with a special thanks to Brian Hoover and his colleagues for conceiving of and promoting the special scattering session), and to the SPIE staff who did so much to make this conference part of the much larger Optics and Photonics Symposium. It is our hope that readers of this proceedings volume will benefit from these combined efforts and will join us for future discussions of optical polarization.

Joseph A. Shaw J. Scott Tyo 
Downloaded From: https://www.spiedigitallibrary.org/conference-proceedings-of-spie on 26 Apr 2023

Terms of Use: https://www.spiedigitallibrary.org/terms-of-use 